\title{
GRV_D_inv: A graphical user interface for 3D forward and inverse modeling of gravity data
}

\author{
L.T. Pham ${ }^{1}$, E. Oksum ${ }^{2}$, M.N. Dolmaz ${ }^{2}, 2021$ \\ ${ }^{1}$ University of Science, Vietnam National University, Faculty of Physics, Hanoi, Vietnam \\ ${ }^{2}$ Süleyman Demirel University, Department of Geophysical Engineering, Isparta, Turkey \\ Received 15 December 2020
}

\begin{abstract}
This paper presents a new gravity inversion tool GRV_D_inv, specifically a GUI-based Matlab code developed to determine the three-dimensional depth structure of a density interface. The algorithm used performs iteratively in the frequency-domain based on a relationship between the Fourier transforms of the gravity data and the sum of the Fourier transforms of the powers of the depth to the interface. In this context, the proposed code is time-efficient in computations, and thus, it is capable of handling large arrays of data. The GUI-enabled interactive control functions of the code enable the user with easy control in setting the parameters for the inversion strategy prior the operation, and allow optional choice for displaying and recording of the outputs data without requiring coding expertise. We validated the code by applying it to both noise-free and noisy synthetic gravity data produced by a density interface; we obtained good correlation between the calculated ones and the actual relief even in the presence of noise. We also applied the code to a real gravity data from Brittany (France) for determining the 3D Moho interface as a practical example. The recovered depths from the code compare well with the published Moho structures of this study area.
\end{abstract}

Key words: Gravity forward, gravity inversion, fast Fourier transform, Matlab.

Introduction. Many different methods have been presented over time to solve the problem of mapping a 3D density interface from gravity data. The first group of methods is based on the space domain techniques that divided geologic structures into rectangular blocks [Cordell, Henderson, 1968; Starostenko, Legostaeva, 1998; Pham et al., 2020]. Most existing space-domain algorithms utilize either the stacked prism model of [Bott, 1960] or the polygonal model of [Talwani et al., 1959]. The algorithms developed by [Talwani, Ewing, 1960; Cordell, Henderson, 1968; Dyrelius, Vogel, 1972; Švancara, 1983; Murthy, Rao, 1989, 1993; Mickus, Peeples, 1992; Barbosa et al., 1997, 1999; Babu, 1997; Mendonca, 2004; Pallero et al., 2015] calculated the total gravity anomaly at a location as the sum of the gravity effect due to all prisms (or all polygon sides). Therefore, the major disadvantage of these algorithms is the slow computation of gravity responses. The second group in- cludes the FFT-based methods based on rearrangement of forward algorithm of [Parker, 1972], e.g. [Oldenburg, 1974; Granser, 1986, 1987; Reamer, Ferguson, 1989; Guspi, 1993; Pilkington, 2006; Zhang et al., 2015; Wu, Lin, 2017]. The methods utilize the relationship between the Fourier transforms of the gravity data and the sum of the Fourier transforms of the powers of the depth to the interface. The main advantage of these methods is the rapid calculation of gravity anomalies that leads them to be computer time-efficient practical applications. However, on the other hand, their constraints in practice are that they require a predetermined average depth of the interface and a high-cut filter to ensure convergence of the inversion procedure [Oldenburg, 1974; Pham, Do, 2017; Pham et al., 2018-2020]. Based on Parker-Oldenburg method, a number of computer programs are available, for instance, [Nagendra et al., 1996] developed computer programs in FORTRAN 
language for the interpretation of 2D gravity data, and [Shin et al., 2006] for the analysis of 3D gravity data. [Gomez-Ortiz, Agarwal, 2005] presented a MATLAB code for inverting the gravity anomaly over a 3D density interface by Parker-Oldenburg's algorithm. The code has been used later by many other researchers for interpreting real data from different parts of the world [Ouyed et al., 2010; Kaya, 2010; Hsieh et al., 2010; Van der Meijde et al., 2013; Tugume et al., 2013; Oruç, 2014; Oruç et al., 2017; Grigoriadis et al., 2015; Gao et al., 2016; Oruç, Sönmez, 2017; Altinoğlu et al., 2018; Nguiya et al., 2019 and among others]. However, a recent paper published by [Gao, Sun, 2019] showed that [Gomez-Ortiz, Agarwal, 2005] misused Parker's formula, thereby leading to incorrect forward and inversion results.

This paper aimes to present an alternative software as a time-efficient gravity inversion tool to determine the 3D depth structure of a density interface related to the observed gravity anomalies. The algorithm linked to the code GRV_D_inv.m is built in Matlab including a graphical interface, which makes it easy for the user to configure the required presets prior an inversion or forward procedure simply without any need of coding experience. The software has been tested for its practical application and accuracy on both synthetic and actual gravity data.

Theory. Describing the model space by a three-dimensional Cartesian coordinate system where its pair-wise perpendicular axes are $x, y$ and $z$ pointing towards east, north and positive downwards, respectively, the 3D expression of the gravity anomaly in the Fourier domain due to a uniform layer of material is given by [Gao, Sun, 2019]:

$$
\begin{gathered}
F[\Delta g(x, y)]= \\
=-2 \pi \gamma \rho e^{\left(-|k| z_{0}\right)} \sum_{n=1}^{\infty} \frac{(-|k|)^{n-1}}{n !} F\left[h^{n}(x, y)\right],
\end{gathered}
$$

where $\rho$ is the density contrast, $\gamma$ is denotes the gravitational constant, $h$ is the interface topography at the reference depth $z_{0}, F[$ ] denotes the Fourier transform operator, $k=\sqrt{k_{x}^{2}+k_{y}^{2}}$ where $k_{x}$ and $k_{y}$ are the wavenumbers along the plane direction. Simple rearrangement of Eq. (1) readily leads

$$
\begin{gathered}
h(x, y)=F^{(-1)}\left[-\frac{F[\Delta g(x, y)] e^{|k| z_{0}}}{2 \pi \gamma \rho}-\right. \\
\left.-\sum_{n=2}^{\infty} \frac{(-|k|)^{n-1}}{n !} F\left[h^{n}(x, y)\right]\right],
\end{gathered}
$$

where F-1[ ] symbolizes the inverse Fourier transform.

Hereby, Eq. (2) can be used through an iterative inversion procedure to estimate the depth to the undulating density interface. The procedure begins by a preset model of the depth $h$, for instance zero for all. With this initial starter model, taking the inverse Fourier transform of the first term of Eq. (2) leads the first approximation of the topography interface $h$. A new set of depth estimate is then calculated by using the $h$ values from the previous step again in equation Eq. (2). Updating for a new depth estimate h continues until a desired fit between two successive depth estimates is achieved whereas the root mean square error (RMS) can be used as the measure of this goodness

$$
\mathrm{RMS}=\sqrt{\frac{\sum_{i=1}^{M} \sum_{j=1}^{N}\left(h_{i, j}^{t+1}-h_{i, j}^{t}\right)^{2}}{M \times N}},
$$

where $M$ and $N$ are the numbers of grid size in north and east, respectively, $t$ stands for the iteration step.

To ensure the convergence of the inverse series in Eq. (2), a low-pass filter $B(k)$ is applied during the calculation. The filter is defined in the following equation [Oldenburg, 1974]

$$
\begin{gathered}
B(k)=\left\{\frac{1}{2}\left[1+\cos \left(\frac{k-2 \pi \mathrm{WH}}{2(\mathrm{SH}-\mathrm{WH})}\right)\right]\right. \\
0 \\
|k / 2 \pi|<\mathrm{WH} \\
\mathrm{WH} \leq|k / 2 \pi| \leq \mathrm{SH}, \\
|k / 2 \pi|>\mathrm{SH}
\end{gathered}
$$

where SH and WH define the roll-off frequen- 
cies of the filter design. The filter passes all the frequencies lower than $\mathrm{WH}$, attenuates between $\mathrm{WH}$ and $\mathrm{SH}$, and cuts off all the frequencies above the SH frequency. An appropriate choice of the roll-off frequencies can be obtained by spectrum analysis of the observed gravity anomaly. Using high-cut filtering results in loss of information's at high frequencies induced by near-surface structures, hence the gravity anomalies due to the inverted depths do not necessarily fit the highfrequency content of the actual anomaly.

Overview of the GRV_D_inv GUI. The GRV_D_inv code is supported by a functional user interface including graphical control functions that allow the user to customize the inversion/forward modeling configurations and setting of the output export formats. When the first time the code is run, it opens the inversion panel as the main graphical interface covering the entire screen. Fig. 1 illustrates the configuration of this panel structure. It includes graphical control items for loading of gridded gravity data, editable cells for settings of the field and filtering parameters, the iteration stop criterion, and a confirmation button that initiates the inversion procedure. The remaining part of the panel contains the input map and its spectrum display area and the display area of the obtained outputs. The interactive [LOAD DATA] menu item at the top left of the panel is used to import the gridded gravity data set which supports the grid formats $\left({ }^{*}\right.$.grd) of the Surfer program (Golden Software). The mesh grid intervals to the east and north are required to be equal and any blank in input is not allowed. After completion of the data loading, the label of the data-loading item is replaced with the file name of the input, and a contour map and a spectrum graph corresponding to the input data are displayed. Next, the set of the density contrast, the mean depth of the density interface, the roll-off frequency parameters of the filtering, and the stopping criterion of the inversion are required. Distances of the map units are expressed in $\mathrm{km}$, the gravity in $\mathrm{mGal}$ and the unit of density contrast in $\mathrm{g} / \mathrm{cm}^{3}$. The set of the $\mathrm{SH}$ and $\mathrm{WH}$ roll-off frequency values can be done either by entering them manually into the corresponded edit boxes or interactively by mouse controls on the spectrum graph. The iterative procedure stops when the goodness of the fit between two successive depth estimates is below the predefined RMS threshold or when it completes the preset limit number of iterations.

After validating the entries, the process

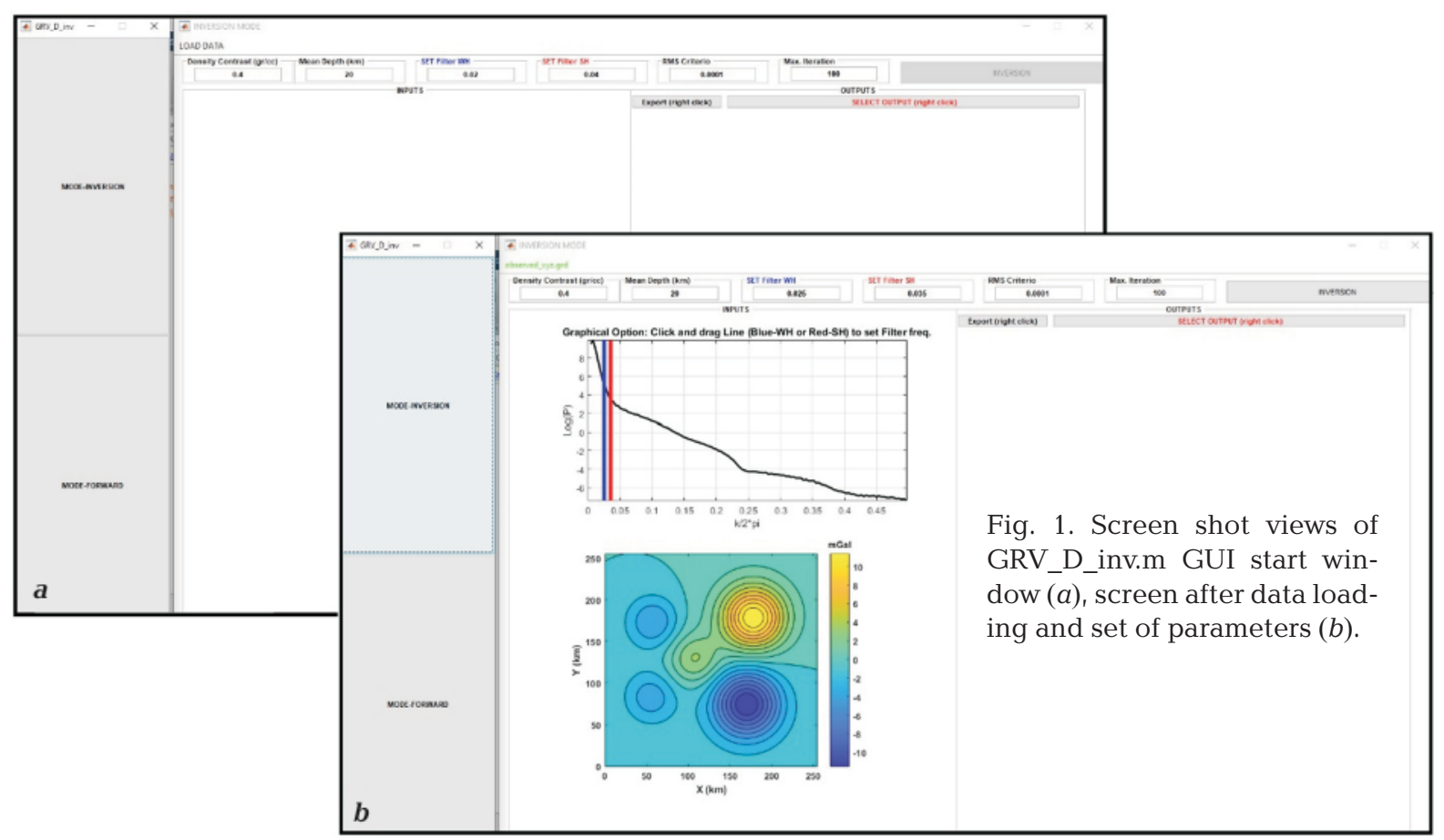


Fig. 2. Screen shot view of the output control panel and some presentative plots after a complete interpretation.
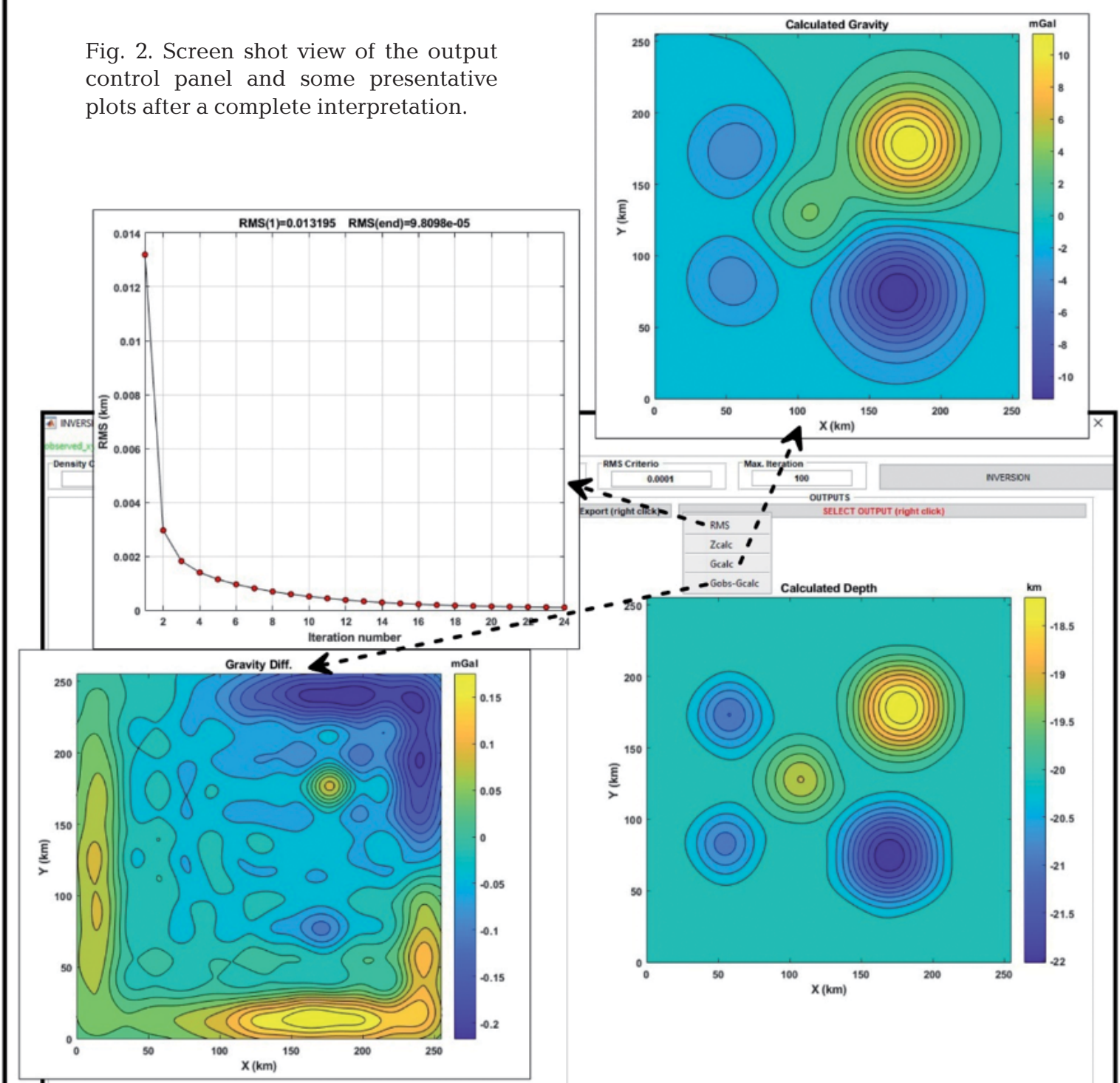

starts with building the initial depth estimates from Eq. (2) and uses them again in Eq. (2) for their improvement. This operation continues until the matching criterion between two successive depth estimates is achieved. Finally, the code records the gravity response and the inverted basement depths obtained at the stopping iteration step, the residual between the actual and modelled gravity anomalies and the values of RMS after each iteration. Following, the code enables us to display or to export any of the output either in numeric or in image format by using the menu items at the output panel (Fig. 2). The results are exported with a user-defined file name common for all the outputs. The code automatically adds an informative extension of the available output. Formats for numeric exports $\left({ }^{*}\right.$. grd,${ }^{*}$.dat) are compatible with the formats of Golden Software whereas the image exports are supplied with portable network graphic format (*.png) of $300 \mathrm{dpi}$ in resolution. Additionally, the GRV_D_inv code also includes a user panel enabled by the [MODE-FORWARD] menu at the bottom left of the main GUI for generating computed gravity anomalies of a certain depth model. The program also allows the user to switch back to the inversion panel via the MODE INVERSION menu item located also on the 


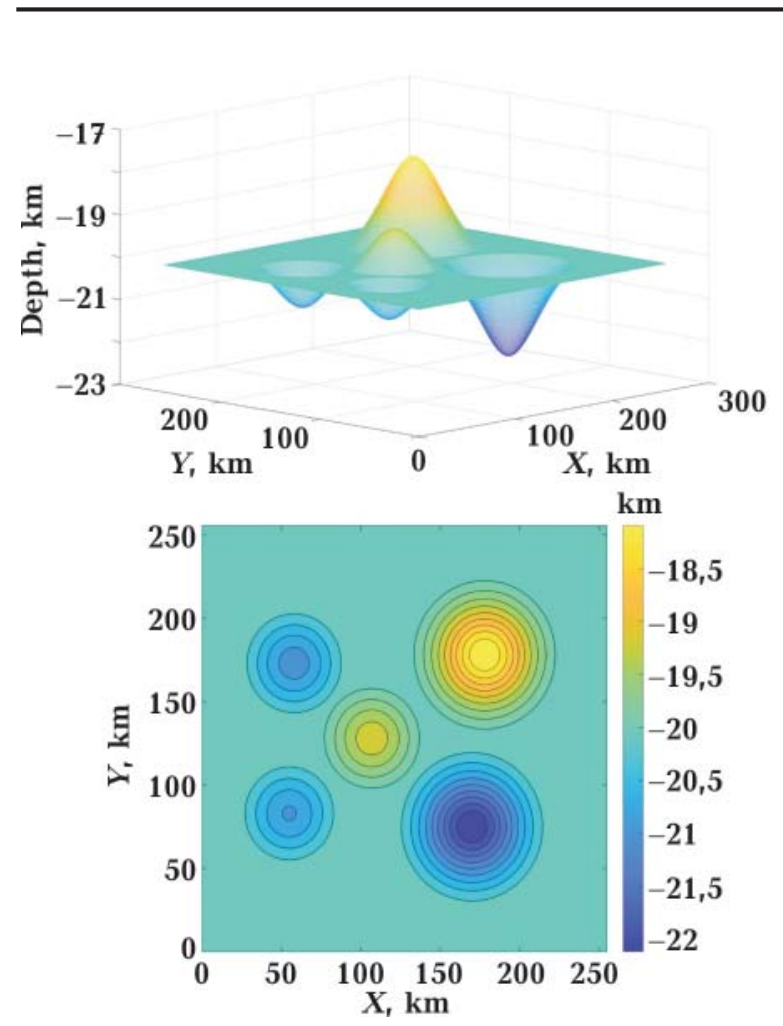

Fig. 3. The depth model interface used to generate theoretical gravity data.

left side of the screen.

Synthetic data application. The applicability and effectiveness of the above-described program is demonstrated by the inversions of noise-free and noise corrupted gravity data sets synthetically produced from a simulated 3D density interface. Fig. 3 shows the 3D and plan views of the topography of the interface with an average depth of $20 \mathrm{~km}$. The data set is calculated through Eq. 1 on a $256 \times 256$ mesh grid of $1 \mathrm{~km}$ intervals with using a density contrast of $0.4 \mathrm{~g} / \mathrm{cm}^{3}$. In the first case, the program is applied to reconstruct the density interface geometry from the noise-free anomaly. Fig. 4, a displays the noise-free gravity anomaly map due to the model in Fig. 3. For the inversion of this data, the high-cut filter frequency parameters were selected as $\mathrm{SH}=0.035 \mathrm{~km}^{-1}$ and $\mathrm{WH}=0.025 \mathrm{~km}^{-1}$. The iterative process performed twenty-fouriterations to fall below the preset allowable RMS of $10^{-4} \mathrm{~km}$ between two successive interface approximations. The RMS after the initial stage was $0.0132 \mathrm{~km}$ and reduced to $9.8098 \cdot 10^{-5} \mathrm{~km}$ at the stopping step (Fig. 4, f). Fig. $4, b$ shows the geometry of the estimated density interface and Fig. $4, d$ the residual between these and the actual density interface. Here, the absolute depth differences between the actual model and the re-constructed one are mainly less than $0.1 \mathrm{~km}$; hence, the estimated relief well represents the true model. The RMS between them is $0.0291 \mathrm{~km}$. Fig. $4, c$ is the calculated gravity anomaly due to the inverted density interface shown in Fig. $4, b$. By comparing of Figs. 4, $a$ and 4, $c$, one can observe that the calculated gravity anomalies are also very close in shape to the original gravity anomalies. The residuals between them (Fig. $4, e$ ) range from -0.2171 to $0.1965 \mathrm{mGal}$ and the RMS is $0.0745 \mathrm{mGal}$.

The sensitivity of the proposed code to noise-corrupted anomaly observations is analyzed in the second example. In this case, the theoretical observations in Fig. 4, a were contaminated with random noise of amplitude $10 \%$ of the original data. Fig. 5, $a$ shows the noise-corrupted gravity data. For inverting this data, the roll-off frequencies of the high-cut filter have been set as $\mathrm{SH}=0.035 \mathrm{~km}^{-1}$ and $\mathrm{WH}=0.025 \mathrm{~km}^{-1}$. The inversion process iterated until the RMS between two successive interface approximations drops below the threshold set $10^{-4} \mathrm{~km}$ value. In this case, the RMS error decreased from $0.0143 \mathrm{~km}$ at the first iteration to $9.8209 \cdot 10^{-5} \mathrm{~km}$ at the end of twenty-fifth iteration (Fig. 5, f). The inverted depths and the modeled gravity anomalies after the termination step are given in Figs. 5, $b$ and $5, c$, respectively. Although the input data is noisy, it can be seen that the inverted depths (Fig. 5, b) still matches closely with those of the actual model given in Fig. 3 where the residuals between them are in general less than $0.1 \mathrm{~km}$ (Fig. 5, d). Consequently, the gravity response of the estimated depth construct (Fig. 5, b) also correlates well with the original model gravity anomaly. The difference between the original model and the calculated gravity anomaly is shown in Fig. 5, $e$ where the RMS error between them is only $0.1230 \mathrm{mGal}$.

Field Example. The functional applicability of the proposed code is also demonstrated by interpreting a real gravity anomaly from 

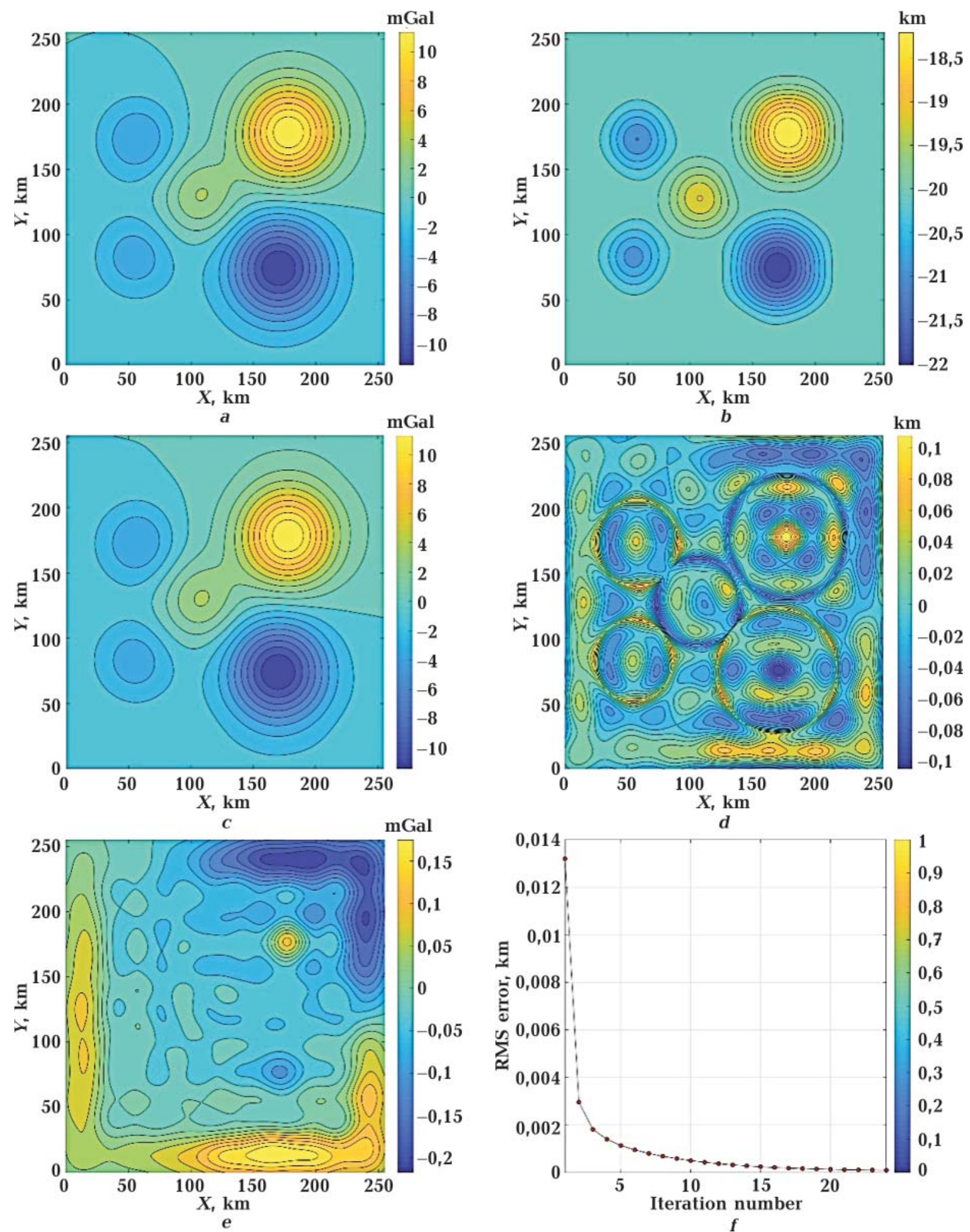

Fig. 4. Inversion results for noise-free data example, $(a)$ theoretical gravity anomalies, $(b)$ the estimated depths from the code application to the model data, $(c)$ calculated gravity anomalies from the inverted interface, $(d)$ the residuals between the actual and computed depths, (e) the residual between the actual and computed gravity anomalies, (f) plot of RMS errors obtained during the on-going iterative process. 


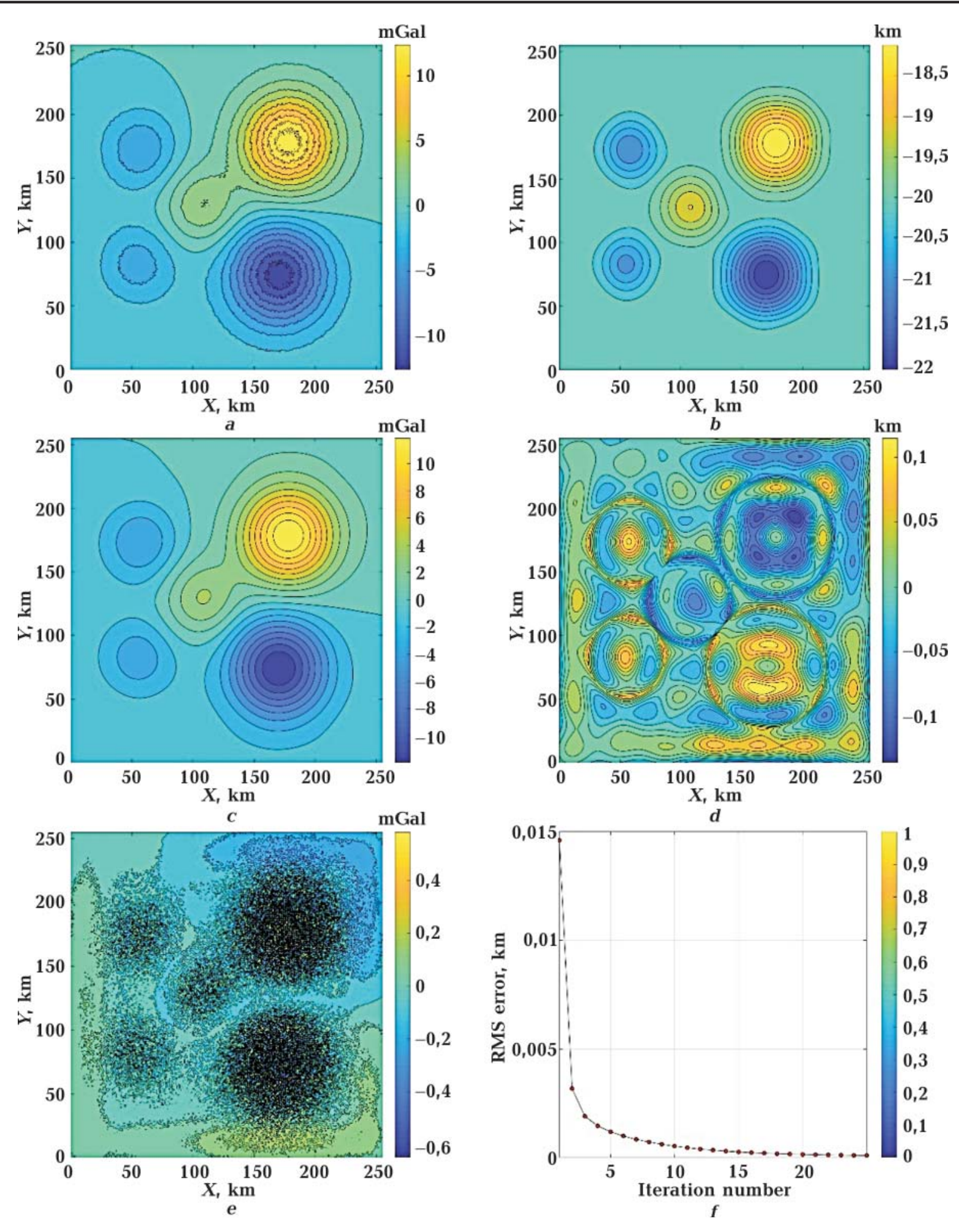

Fig. 5. Inversion results for noise-corrupted data example, (a) theoretical gravity anomalies including $10 \%$ noise (b) the estimated depths from the code application to the noise-corrupted data, (c) calculated gravity anomalies from the inverted interface, $(d)$ the residuals between the actual and computed depths, $(e)$ the residual between the actual and computed gravity anomalies, $(f)$ plot of RMS errors obtained during the on-going iterative process.

Brittany, France, previously analyzed as well by other researchers for estimating the Moho depths of the region, i.e. [Lefort, Agarwal, 2000; Gomez-Ortiz, Agarwal, 2005]. The lo- 
cation of the study area is shown in Fig. 6 . Fig. 7, a shows the residual gravity anomaly ascribed to the Moho interface in Brittany, which obtained from [Gomez-Ortiz, Agarwal, 2005] program on a $51 \times 51$ mesh point with square grid intervals of $4 \mathrm{~km}$. The four input parameters are used for the inversion of this data by the present code. They are the density contrast between the lower crust and the upper mantle as $0.4 \mathrm{~g} / \mathrm{cm}^{3}$ and a mean depth of the density interface as $30 \mathrm{~km}$ [GomezOrtiz, Agarwal, 2005], the roll-off frequency parameters of the high-cut filter chosen as $\mathrm{SH}=0.012 \mathrm{~km}^{-1}$ and $\mathrm{WH}=0.01 \mathrm{~km}^{-1}$ [Lefort, Agarwal, 2000]. Here, the inversion scheme performed seventy-one iterations to fall below an allowable RMS error of $2 \cdot 10^{-4} \mathrm{~km}$ between two successive depth approximations (Fig. 8). The estimated depths of the Moho interface and the gravity field generated from these depths are given in Figs. 7, $b$ and $7, c$, respectively. As can be seen by comparing Fig. 7, $a$ and $7, c$, the calculated anomalies fit very closely with the observations. The differences between them are generally less than $1 \mathrm{mGal}$ (Fig. 7, $d$ ), and the RMS error is only $0.24 \mathrm{mGal}$. Further, the closeness of the fit between the calculated and observed anomalies is obtained better in this study when compared to those obtained by [Gomez-Ortiz, Agarwal, 2005] with a maximum difference of $1.5 \mathrm{mGal}$. The depth estimates from the present study ranges from $27.77 \mathrm{~km}$ to $32.38 \mathrm{~km}$ (Fig. 7, b). For comparison, Fig. 7, e shows the geometry of the density interface estimated by [Gomez-Ortiz, Agarwal, 2005] and Fig. 7, $f$ the interpreted model by [Lefort, Agarwal, 2000] using an inversion method described by [Tsuboi, 1983]. Although the depths obtained from this study are quite similar to those obtained by [Gomez-Ortiz, Agarwal, 2005], a few deviations can be observed, for example, the deeper parts of the interface observed in the southeast of the area show a NW-SE directional trend, which is also figured in the structure of [Lefort, Agarwal, 2000]. By and large, the result obtained by the application of the code to the gravity data of Brittany is comparable with those reported

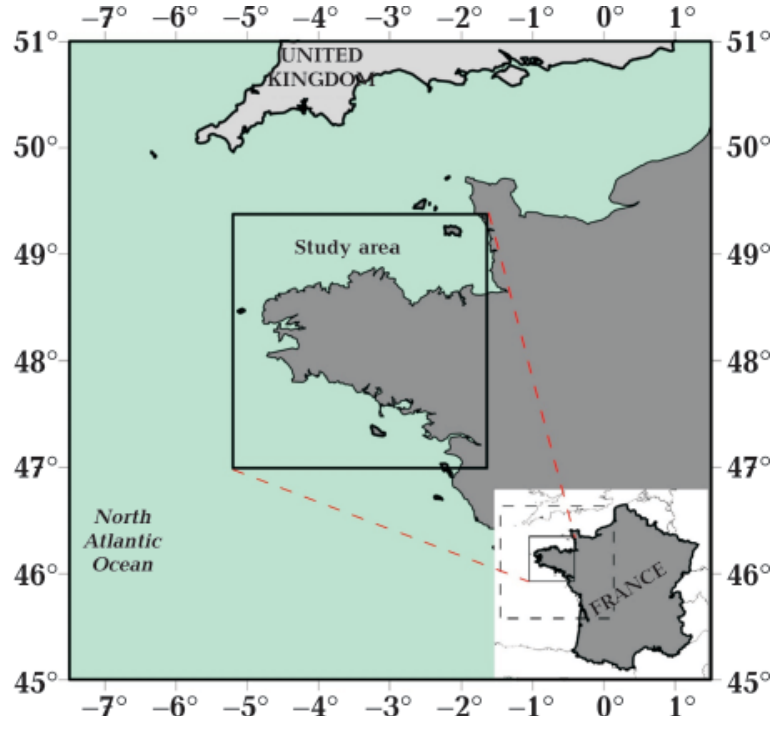

Fig. 6. Location of the study area.

by [Lefort, Agarwal, 2000].

Conclusions. A GUI-based Matlab program GRV_D_inv is presented to estimate the relief of a density interface from gravity anomalies by an iterative procedure. The algorithm linked to the code operates iteratively in the frequency-domain. Hence, the computational speed is fast and therefore it can be a computer time-efficient practical application in processing large data sets. The inversion of a $256 \times 256$ gridded data completed within 24 iterations in a PC equipped with a $2.4 \mathrm{GHz}$ central processing unit (CPU) took only $3.9 \mathrm{~s}$, which can be considered as a short duration for this kind of inverse problem. As a further advantage, the code is supported with a practical user interface that includes interactive control functions that makes it easy for the user to configure the settings prior the inversion as well as to manage the extraction of the outputs with optional preference without requiring any coding expertise.

The present code has been tested for its practical application and accuracy on both noise-free and noise corrupted synthetic gravity data produced from a 3D density interface model, as well as on a real gravity data from Brittany, France, where the results were compared with those of previous studies. The depth results inverted from the noisefree data well matched the real structure. Al- 

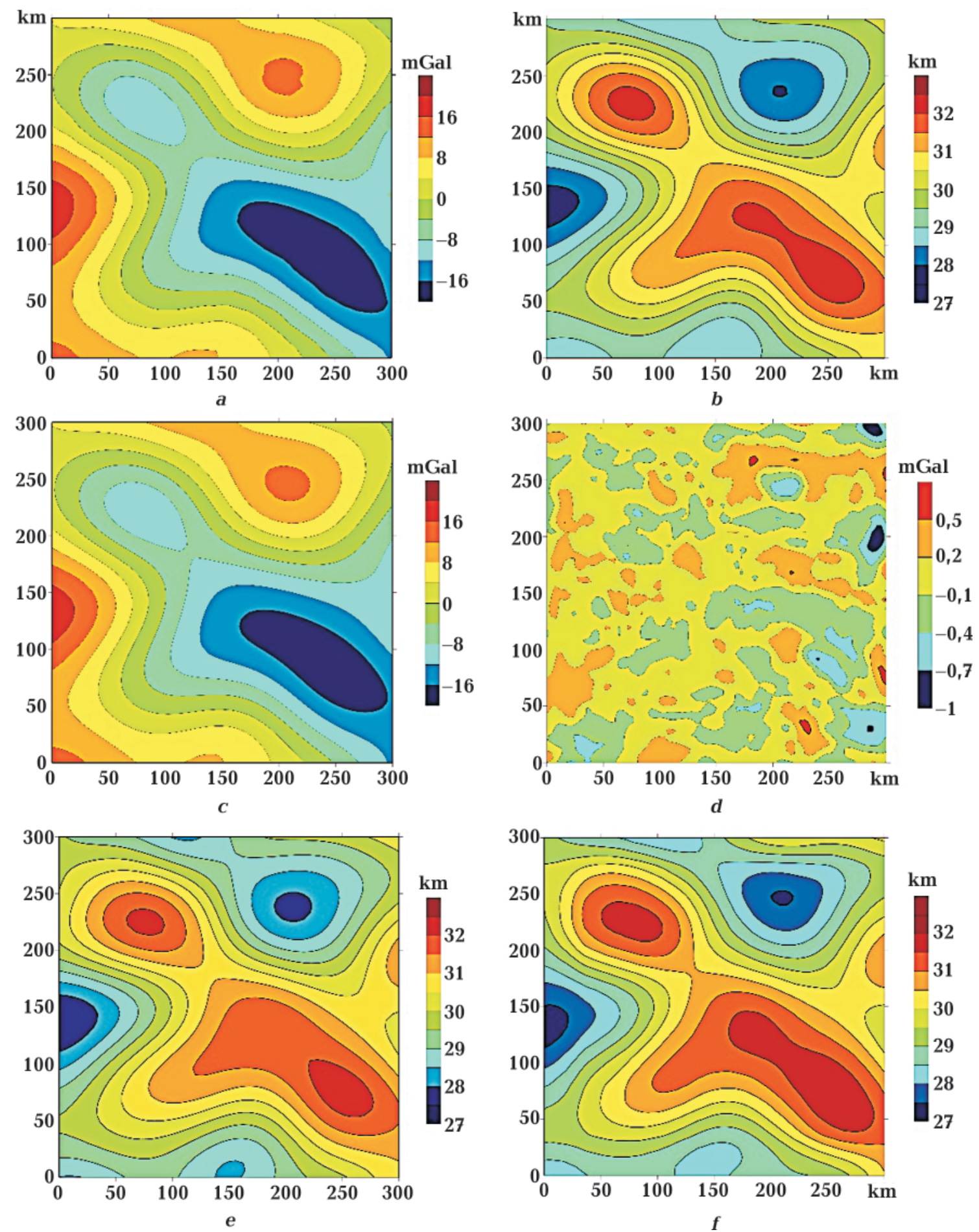

Fig. 7. The real field example, $(a)$ the residual gravity anomaly from Brittany, France, $(b)$ the estimated Moho relief from practice of the proposed code,$(c)$ the gravity anomaly calculated from the estimated interface, $(d)$ the difference between the actual and the modeled gravity anomalies, (e) the Moho relief reported by [Gomez-Ortiz, Agarwal, 2005], (f) the Moho relief reported by [Lefort, Agarwal, 2000].

though there are some minor deviations between the actual and estimated depths from the noise-corrupted data sample, the results are still in good agreement even the given gravity anomalies are noisy. The obtained depth structure of the Moho in Brittany from 


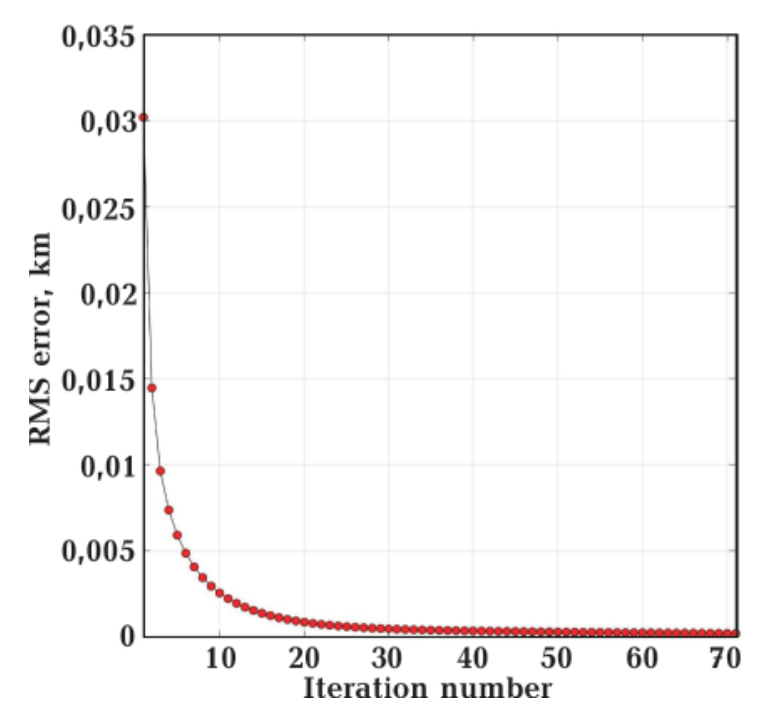

Fig. 8. Variation of RMS error versus iteration number obtained for real field example.

\section{References}

Altinoğlu, F.F., Sari, M., \& Aydin, A. (2018) Shallow crust structure of the Büyük Menderes graben through an analysis of gravity data. Turkish Journal of Earth Sciences, 27, 421-431.

Babu, H.V.R. (1997). Average crustal density of the Indian Lithosphere - An inference from gravity anomalies and deep seismic soundings. Journal of Geodynamics, 23(1), 1-4. https:// doi.org/10.1016/S0264-3707(96)00025-7.

Barbosa, V.C.F., Silva, J.B.C., \& Medeiros, W.E. (1997). Gravity inversion of basement relief using approximate equality constraints on depths. Geophysics, 62(6), 1745-1757. https:// doi.org/10.1190/1.1444275.

Barbosa, V.C.F., Silva, J.B.C., \& Medeiros, W.E. (1999). Gravity inversion of a discontinuous relief stabilized by weighted smoothness constraints on depth. Geophysics, 64(5), 1429 1437. https://doi.org/10.1190/1.1444647.

Bott, M.H.P. (1960). The use of rapid digital computing methods for direct gravity interpretation of sedimentary basins. Geophysical Journal International, 3(1), 63-67. https://doi. org/10.1111/j.1365-246X.1960.tb00065.x.

Cordell, L., \& Henderson, R.G. (1968). Iterative three-dimensional solution of gravity anomaly data using a digital computer. Geophysics, 33(4), 596-601. https://doi.org/10.1190/1.1439955. the present study is in close agreement with the previously published structures by other studies. As a result, the proposed code has proved effective in interpreting gravity anomalies to determine the depth structure of a density interface and can therefore be considered as a practical tool for modeling purposes in geophysical applications.

Code availability. The GRV_D_invis a free program and it can be downloaded together with synthetic data files and a user manual from the web site [https://github.com/ PhamLT/GRV_D_inv].

Acknowledgements. Luan Thanh Pham was funded by Vingroup Joint Stock Company and supported by the Domestic Master/ PhD Scholarship Programme of Vingroup Innovation Foundation (VINIF), Vingroup Big Data Institute (VINBIGDATA).

Dyrelius, D., \& Vogel, A. (1972). Improvement of convergency in iterative gravity interpretation. Geophysical Journal International, 27(2), 195205. https://doi.org/10.1111/j.1365-246X.1972. tb05771.x.

Hsieh, H.H., Yen, H.Y., \& Shih, M.H. (2010). Moho depth derived from gravity data in the Taiwan Strait Area. Terrestrial, Atmospheric and Oceanic Sciences, 21(2), 235-241. https://doi. org/10.3319/TAO.2009.03.05.01(T).

Gao, G., Kang, G., Li, G., Bai, C., \& Wu, Y. (2016). An analysis of crustal magnetic anomaly and $\mathrm{Cu}-$ rie surface in west Himalayan syntaxis and adjacent area. Acta Geodaetica et Geophysica，52(3), 407-420. https://doi.org/10.1007/ s40328-016-0179-z.

Gao, X., \& Sun, S. (2019). Comment on «3DINVER.M:AMATLAB program to invert the gravity anomaly over a 3D horizontal density interface by Parker-Oldenburg's algorithm». Computers \& Geosciences, 127, 133-137. https:// doi.org/10.1016/j.cageo.2019.01.013

Gomez-Ortiz, D., \& Agarwal, B.N.P. (2005). 3DINVER.M: a MATLAB program to invert gravity anomaly over a 3-D horizontal density interface by Parker-Oldenburg's algorithm. Computers \& Geosciences, 31(4), 513-520. https://doi.org/10.1016/j.cageo.2004.11.004.

Guspí, F. (1992). Three-dimensional Fourier 
gravity inversion with arbitrary density contrast. Geophysics, 57(1), 131-135. https://doi. org/10.1190/1.1443176.

Granser, H. (1986). Convergence of iterative gravity inversion. Geophysics, 51(5), 1146-1147. https://doi.org/10.1190/1.1442169.

Granser, H. (1987). Nonlinear inversion of gravity data using the Schmidt-Lichtenstein approach. Geophysics, 52(1), 88-93. https://doi. org/10.1190/1.1442243.

Grigoriadis, V.N., Tziavos, I.N., Tsokas, G.N., \& Stampolidis, A. (2015). Gravity data inversion for Moho depth modeling in the Hellenic area. Pure and Applied Geophysics, 173(4), 1223-1241. https://doi.org/10.1007/s00024-015-1174-y.

Kaya, C. (2010). Deep crustal structure of northwestern part of Turkey. Tectonophysics, 489(14), 227-239. https://doi.org/10.1016/j.tecto.2010.04.019.

Lefort, J.P., \& Agarwal, B.N.P. (2000). Gravity and geomorphological evidence for a large crustal bulge cutting across Brittany (France): a tectonic response to the closure of the Bay of Biscay. Tectonophysics, 323(3-4), 149-162. https:// doi.org/10.1016/S0040-1951(00)00103-7.

Mendonca, C.A. (2004). Inversion of gravity field inclination to map the basement relief of sedimentary basins. Geophysics, 69(5), 1240-1251. https://doi.org/10.1190/1.1801940.

Mickus, K.L., \& Peeples, W.J. (1992). Inversion of gravity and magnetic data for the lower surface of a 2.5 dimensional sedimentary basin1. Geophysical Prospecting, 40(2), 171-193. https:// doi.org/10.1111/j.1365-2478.1992.tb00370.x.

Murthy, I.V.R., \& Rao, S.J. (1989). A Fortran 77 program for inverting gravity anomalies of twodimensional basement structures. Computers \& Geosciences, 15(7), 1149-1156. https://doi. org/10.1016/0098-3004(89)90126-X.

Murthy, I.V.R., \& Rao, P.R. (1993). Inversion of gravity and magnetic anomalies of two-dimensional polygonal cross sections. Computers \& Geosciences, 19(9), 1213-1228. https://doi. org/10.1016/0098-3004(93)90026-2.

Nagendra, R., \& Prasad, P.V.S., Bhimasankaram, V.L.S. (1996). Forward and inverse computer modeling of gravity field resulting from a density interface using Parker Oldenburg method. Computers \& Geosciences, 22(3), 227
231. https://doi.org/10.1016/0098-3004(95) 00075-5.

Nguiya, S., Lemotio, W., Njandjock, N.P, Pemi, M.M., Tokam, A.P.K., \& Ngatchou, E. (2019). 3D Mafic Topography of the Transition Zone between the North-Western Boundary of the Congo Craton and the Kribi-Campo Sedimentary Basin from Gravity Inversion. International Journal of Geophysics, 2019, 7982562. https://doi.org/10.1155/2019/7982562.

Oldenburg, D.W. (1974). The inversion and interpretation of gravity anomalies. Geophysics, 39(4), 526-536. https://doi.org/10.1190/ 1.1440444.

Oruç, B. (2014). Structural interpretation of southern part of western Anatolian using analytic signal of the second order gravity gradients and discrete wavelet transform analysis. Journal of Applied Geophysics, 103, 82-98. https:// doi.org/10.1016/j.jappgeo.2014.01.008.

Oruç, B., Gomez-Ortiz, D., \& Petit, C. (2017). Lithospheric flexural strength and effective elastic thicknesses of the Eastern Anatolia (Turkey) and surrounding region. Journal of Asian Earth Sciences, 150, 1-13. https://doi.org/10.1016/j. jseaes.2017.09.015.

Oruç, B.,\& Sönmez, T. (2017). The rheological structure of the lithosphere in the Eastern Marmara region, Turkey. Journal of Asian Earth Sciences, 139, 183-191. https://doi.org/10.1016/j. jseaes.2017.02.041.

Ouyed, M., Idres, M., Bourmatte, A., Boughacha, M.S., Samai, S., Yelles, A., Haned, A., \& Aidi, C. (2010). Attempt to identify seismic sources in the eastern Mitidja basin using gravity data and aftershock sequence of the Boumerdes (May 21, 2003; Algeria) earthquake. Journal of Seismology, 15(2), 173-189. https://doi.org/10.1007/s10950-010-9218-3.

Parker, R.L. (1972). The rapid calculation of potential anomalies. Geophysical Journal International, 31(4), 447-455. https://doi.org/10.1111/ j.1365-246X.1973.tb06513.x.

Pallero, J.L.G., Fernandez-Martinez, J.L., Bonvalot, S., \& Fudym, O. (2015), Gravity inversion and uncertainty assessment of basement relief via particle swarm optimization. Journal of Applied Geophysics, 116, 180-191. https:// doi.org/10.1016/j.jappgeo.2015.03.008.

Pham, L.T., \& Do, T.D. (2017). Estimation of sedimentary basin depth using the hybrid tech- 
nique for gravity data. VNU Journal of Science: Mathematics-Physics, 33(2), 48-52. https://doi. org/10.25073/2588-1124/vnumap.4203.

Pham, L.T., Oksum, E., \& Do, T.D. (2018). GCH gravinv: A MATLAB-based program for inverting gravity anomalies over sedimentary basins. Computers \& Geosciences, 120, 40-47. https:// doi.org/10.1016/j.cageo.2018.07.009.

Pham, L.T., Do, T.D., Oksum, E., \& Le, S.T. (2019). Estimation of Curie point depths in the Southern Vietnam continental shelf using magnetic data. Vietnam Journal of Earth Sciences, 41(3), $216-228$.

Pham, L.T., Oksum, E., Gómez-Ortiz, D., \& Do, T.D. (2020). MagB_inv: A high performance Matlab program for estimating the magnetic basement relief by inverting magnetic anomalies. Computers \& Geosciences, 134, 104347. https://doi. org/10.1016/j.cageo.2019.104347.

Pilkington, M. (2006). Joint inversion of gravity and magnetic data for two-layer models. Geophysics, 71, L35-L42. https://doi. org/10.1190/1.2194514.

Reamer, S.K., \& Ferguson, J.F. (1989). Regularized two-dimensional Fourier gravity inversion method with application to the Silent Canyon caldera, Nevada. Geophysics, 54, 486-496. https://doi.org/10.1190/1.1442675.

Shin, Y.H., Choi, K.S., \& Xu, H. (2006). Three-dimensional forward and inverse models for gravity fields based on the Fast Fourier Transform. Computers \& Geosciences, 32(6), 727-738. https://doi.org/10.1016/j.cageo.2005.10.002.

Starostenko, V.I., \& Legostaeva, O.V. (1998). Calculations of the gravity field from an inhomogeneous, arbitrary truncated vertical rectangular prism. Izvestiya, Physics of the Solid Earth, 34(12), 991-1003.
Švancara, J. (1983). Approximate method for direct interpretation of gravity anomalies caused by surface three-dimensional geologic structures. Geophysics, 48(3), 361-366. https://doi. org/10.1190/1.1441474.

Talwani, M,Worzel, J., \&Ladisman, M. (1959). Rapid gravity computations for two dimensional bodies with application to the Mendocino submarine fracture zone. Journal of Geophysical Research, 64(1), 49-59. https:// doi.org/10.1029/JZ064i001p00049.

Talwani, M. \& Ewing, M. (1960). Rapid computation of gravitational attraction of three-dimensional bodies of arbitrary shape. Geophysics, 25(1), 203-225. https://doi.org/10.1190/1.1438687.

Tsuboi, C. (1983). Gravity. London: George Allen \& Unwin Ltd, 254 p.

Tugume, F., Nyblade, A., Julià, J., \& van der Meijde, M. (2013). Precambrian crustal structure in Africa and Arabia: Evidence lacking for secular variation. Tectonophysics, 609, 250-266. https://doi.org/10.1016/j.tecto.2013.04.027.

Van der Meijde, M., Julià, J., \& Assumpção, M. (2013). Gravity derived Moho for South America. Tectonophysics, 609, 456-467. https://doi. org/10.1016/j.tecto.2013.03.023.

Wu, L., \& Lin, Q. (2017). Improved Parker's method for topographic models using Chebyshev series and low rank approximation. Geophysical Journal International, 209(2), 1296-1325. https://doi.org/10.1093/gji/ggx093.

Zhang, C., Huang, D., Wu, G., Ma, G., Yuan, Y., \& Yu, P. (2015). Calculation of Moho depth by gravity anomalies in Qinghai-Tibet Plateau based on an improved iteration of Parker-Oldenburg Inversion. Pure and Applied Geophysics, 172(10), 2657-2668. https://doi. org/10.1007/s00024-015-1039-4.

\section{Программный пакет GRV_D_inv: графический интерфейс пользователя Аля 3D прямого и обратного моделирования гравитационных Аанных}

\section{А.Т. Фам' , Е. Оксам², М.Н. Аолмаз ${ }^{2}, 2021$}

${ }^{1}$ Научный университет Вьетнамского национального университета, Ханой, Вьетнам

${ }^{2}$ Университет имени Сулеймана Аемиреля, Испарта, Турция

Представлен новый способ решения обратной задачи гравиметрии GRV_D_inv, a именно: на основе кода Matlab разработан графический интерфейс пользователя, 
предназначенный для определения глубинной трехмерной структуры распределения плотности. Используемый алгоритм работает итеративно в частотной области и основан на взаимосвязи между преобразованиями Фурье гравиметрических данных и суммой преобразований Фурье степеней глубины к границе раздела. В этом контексте предлагаемый программный код экономит время вычислений и, следовательно, способен обрабатывать большие массивы данных. Интерактивный контроль функций кода графическим интерфейсом пользователя позволяет пользователю легко управлять настройкой параметров стратегии решения обратной задачи до начала операции по вычислению и оптимально выбирать отображение и запись выходных данных без опыта кодирования. Обоснован код, примененный как к чистым, так и к зашумленным синтетическим данным гравиметрии, полученным с помощью интерфейса определения плотности; получtyf хорошfz корреляциz между расчетными и реальным рельефом даже при наличии искажения шумом. Программный код применен также для интерпретации реальных гравиметрических данных из Бретани (Франция) в качестве практического примера исследования 3D раздела Мохо. Полученные глубины хорошо согласуются с опубликованным строением раздела Мохо в указанном районе исследования.

Ключевые слова: прямое и обратное моделирование гравитационных данных, быстрое преобразование Фурье, код Matlab.

\title{
Програмний пакет GRV_D_inv: графічний інтерфейс користувача Аля 3D прямого і зворотного моделювання гравітаційних Ааних
}

\author{
А.T. Фам', Е. Оксам², М.Н. Аолмаз ${ }^{2}, 2021$ \\ ${ }^{1}$ Научний університет В'єтнамського національного університету, Ханой, В'єтнам \\ ${ }^{2}$ Університет імені Сулеймана Аеміреля, Іспарта, Туреччина
}

Наведено новий спосіб розв'язання оберненої задачі гравіметрії GRV_D_inv, a саме: на основі коду Matlab розроблено графічний інтерфейс користувача, призначений для визначення глибинної тривимірної структури розподілу щільності. Використовуваний алгоритм працює ітеративно в частотному діапазоні й грунтується на взаємозв'язку між перетвореннями Фур'є гравіметричних даних і сумою перетворень Фур'є ступенів глибини до межі поділу. У цьому контексті пропонований програмний код економить час обчислень і, отже, здатний обробляти великі масиви даних. Інтерактивний контроль функцій коду графічним інтерфейсом користувача дає змогу користувачеві легко керувати настроюванням параметрів стратегії розв' язання оберненої задачі до початку операції з обчислення та оптимально вибирати відображення і запис вихідних даних без досвіду кодування. Обгрунтовано код, застосований як до чистих, так і до зашумлених синтетичних даних гравіметрії, отриманих за допомогою інтерфейсу визначення щільності; отримано хорошу кореляцію між розрахунковими і реальним рельєфом навіть за наявності спотворення шумом. Програмний код використано і для інтерпретації реальних гравіметричних даних із Бретані (Франція) як практичний приклад дослідження 3D поділу Мохо. Отримані глибини добре узгоджуються з опублікованою будовою поділу Мохо в цьому районі дослідження.

Ключові слова: пряме і обернене моделювання гравітаційних даних, швидке перетворення Фур'є, код Matlab. 